\title{
Keep your droplets to yourself: Universal use of face masks along with social distancing
}

\author{
Helena Carvalho, ${ }^{1 *}$ Daniel Contaifer Jr., ${ }^{2}$ Renata N. Aranha, ${ }^{3}$ Juliana A. de Matos ${ }^{4}$
}

\begin{abstract}
Introduction: As the COVID-19 pandemic progresses around the world, the universal use of face masks imposes itself as a measure to mitigate the transmission of SARS-CoV-2 and is currently recommended by the World Health Organization. However, its effectiveness as a method of preventing COVID-19 is still controversial. Objective: To review the literature on the universal use of facial masks, including fabric ones, and their recommendations for use. Methods: Narrative review of published studies on the topic. Results: Face masks act predominantly as a source control mechanism, as they capture the droplets expelled by the user when speaking, coughing or sneezing, protecting other people and the environment from contamination by potentially infecting droplets. Evidence of the effectiveness of its universal use as a method of mitigating epidemics of viral respiratory infections is derived from experimental studies and mathematical models. Proper use of facial masks is essential to ensure their effectiveness and prevent damage, and includes covering the nose, mouth and chin, washing the fabric masks with soap and water after use and hand hygiene several times a day, especially when handling the mask. Conclusions: The universal use of facial masks in the context of the COVID-19 pandemic is justified, especially considering the occurrence of virus transmission in the pre-symptomatic period, and should be adopted in conjunction with other measures such as adequate social distance and hygiene from the hands, following the motto "I protect you and you protect me".
\end{abstract}

Keywords: Coronavirus infections; Masks; Prevention \& control.

\section{Resumo}

Mantenha suas gotículas para si mesmo: uso universal de máscaras faciais e distância social

Introdução: À medida que a pandemia de COVID-19 progride em todo o mundo, o uso universal de máscaras faciais se impõe como uma medida para mitigação da transmissão do SARS-CoV-2, sendo atualmente recomendado pela Organização Mundial de Saúde. No entanto, sua eficácia como método de prevenção da COVID-19 ainda é controversa. Objetivo: Revisar a literatura a respeito do uso universal de máscaras faciais, incluindo as de tecido e suas recomendações de uso. Métodos: Revisão narrativa de estudos publicados sobre o tema. Resulta-
1. Department of Basic Sciences Education. Virginia Tech Carilion School of Medicine. Roanoke, VA, USA.

2. Department of Pharmacotherapy and Outcomes Sciences. School of Pharmacy, Virginia Commonwealth University, Richmond, VA, USA.

3. Department of Gynecology and Obstetrics, Faculty of Medical Sciences. State University of Rio de Janeiro, Rio de Janeiro, RJ Brazil.

4. Laboratory for Research on Immunization and Health Surveillance. National Institute of Infectious Diseases Evandro Chagas, Oswaldo Cruz Foundation, Rio de Janeiro, Brazil.

\section{*Correspondence address:}

Department of Basic Science Education

Virginia Tech Carilion School of Medicine

1 Riverside Circle, Suite 202. Roanoke, VA, USA. 24016

E-mail: helena@vt.edu

ORCID: https://orcid.org/0000-0001-9607-2452

BJHBS, Rio de Janeiro, 2020;19(2):114-123

Received on 26/06/2020. Approved on 06/10/2020.

dos: As máscaras faciais atuam predominantemente como um mecanismo de controle de fonte, pois capturam as gotículas expelidas pelo usuário ao falar, tossir ou espirrar, protegendo outras pessoas e o ambiente da contaminação por gotículas potencialmente infectantes. As evidências da eficácia do seu uso universal como método de mitigação de epidemias de infecções respiratórias virais derivam de estudos experimentais e modelos matemáticos. O uso adequado das máscaras faciais é fundamental para garantir sua eficácia e prevenir danos e inclui cobrir o nariz, boca e queixo, lavar as máscaras de tecido com água e sabão após o uso e higienizar as mãos várias vezes ao dia, especialmente ao manipular a máscara. Conclusões: $\mathrm{O}$ uso universal de máscaras faciais no contexto da pandemia de COVID-19 é justificado, especialmente considerando a ocorrência da transmissão do vírus no período pré-sintomático, e deve ser adotado em conjunto com outras medidas como o distanciamento social adequado e a higiene das mãos, seguindo a máxima "eu te protejo e você me protege".

Descritores: Infecções por Coronavírus; Máscaras; Prevenção \& controle. 


\section{Resumen}

\section{Mantén tus gotas para ti: uso universal de mascar- illas junto con distancia social}

Introducción: A medida que avanza la pandemia de COVID-19 en todo el mundo, el uso universal de mascarillas se impone como una medida para mitigar la transmisión del SARS-CoV-2 y actualmente es recomendado por la Organización Mundial de la Salud. Su efectividad como método para prevenir COVID-19 aún es controvertida. Objetivo: Revisar la literatura sobre el uso universal de las máscaras faciales, incluidas las de tela, y sus recomendaciones de uso. Métodos: Revisión narrativa de estudios publicados sobre el tema. Resultados: Las mascarillas actúan predominantemente como un mecanismo de control de la fuente, ya que capturan las gotitas expulsadas por el usuario al hablar, toser o estornudar, protegiendo a otras personas y al medio ambiente de la contaminación por gotitas

\section{Introduction}

The world is experiencing an emergency scenario in dealing with COVID-19. While there is not an effective treatment or vaccine, non-pharmaceutical prevention methods have been adopted as a means of mitigating the spread of its causative virus, SARSCoV-2. These methods comprise different approaches to minimize social contact, from shelter-at-home policies to city lockdown; face mask ordinances; universal symptom survey; contact tracing and quarantine of all confirmed and potential cases and exposed individuals, among others. The effectiveness of these methods should be constantly assessed by monitoring infection rates and effective reproduction numbers, considering data continuously drawn from different sources, including surveillance data and results of serological surveys designed to estimate population immunity. ${ }^{1}$ Many of these methods have been compromised due to limited availability of tests. Non-pharmaceutical methods applied to new viruses are also prone to variabilities in their efficacy due to the necessity of population adherence.

It is currently not possible to identify all carriers due to the lack of available universal testing, besides the limitations of performance of existing tests. In addition, it must be noted that evidence has shown that infected people can be contagious shortly before potencialmente infecciosas. La evidencia de la efectividad de su uso universal como método para mitigar epidemias de infecciones respiratorias virales se deriva de estudios experimentales y modelos matemáticos. El uso adecuado de las mascarillas faciales es fundamental para asegurar su eficacia y evitar daños, e incluye cubrirse la nariz, la boca y el mentón, lavar las mascarillas de tela con agua y jabón después de su uso e higiene de manos varias veces al día, especialmente al manipularlas. la máscara. Conclusiones: Se justifica el uso universal de mascarillas faciales en el contexto de la pandemia COVID-19, especialmente considerando la ocurrencia de transmisión del virus en el período presintomático, debiendo ser adoptado en conjunto con otras medidas como la adecuada distancia social e higiene de las manos, siguiendo la máxima "Yo te protejo y tú me proteges".

Palabras clave: Infecciones por Coronavirus; Mascarillas; Prevencion \& control. symptoms begin, the so-called pre-symptomatic period, i.e., the last 2 days of the incubation period, which can last on average 5-6 days, and up to 14 days. ${ }^{2}$ Preliminary evidence suggests that transmission by truly asymptomatic individuals is also possible. ${ }^{3}$ Therefore, it is advisable to adopt barrier measures, such as the consistent use of face masks by all individuals, along other non-pharmaceutical measures, to mitigate the effects of the pandemic.

In the context of the developing pandemic, the universal use of face masks is a low cost and simple measure that can be easily implemented. However, the recommendation of universal use of face masks by the general population has been delayed by the official health authorities in several countries, causing confusion and controversy about the correct application of the measure. Notwithstanding, the resistance to use face masks seems inconsistent with the knowledge of the virus' transmission, either by droplets from the respiratory tract or by contact with surfaces contaminated by respiratory secretions containing viable viral particles.

In many countries where using masks in public was considered a stigma, now its use has been introduced as a new paradigm of social behavior and health protection. Countries like Austria, Brazil, Czech Republic, China, Hong Kong, Israel, Italy, Japan, Mongolia, Singapore, South Korea, Taiwan, Turkey, and the United 
States have taken varied steps to advocate universal masking as an additional measure to reduce community transmission of SARS-CoV-2.4

Our goal is to review the risks and benefits of universal use of face masks for the general population and recommendations for its use, while contributing to the awareness of the general population about its value.

\section{Non-pharmaceutical Measures Recommended During Pandemic}

Thus far, health authorities have struggled to implement effective measures of mitigation of COVID-19 pandemics. Regardless of the chosen strategy, the economic cost to society will be significant until the pandemic is under control. ${ }^{7}$

At the beginning of the COVID-19 outbreak, all cases of symptomatic patients, regardless of severity of the disease, were usually dealt with by an emergency method of containment, where isolation of all cases is the primary method to control the spread of the disease. This strategy requires the patient to be placed in airborne isolation rooms, under supervision of health care professionals using adequate personal protective and other disposable equipment until active transmission of the virus is ruled out. However, it is estimated that a high percentage of infected patients have minimal or mild symptoms, therefore, the virus would already be silently spreading through the population before detection and isolation occurs. ${ }^{8}$ Evidence has shown that asymptomatic individuals can shed viral particles (defined as a positive PCR test for SARS-CoV-2 on nasopharyngeal swab) with a median duration of 19 days (interquartile range: 15-26 days), while the shortest duration detected is 6 days, and the longest, 45 days. In mild symptomatic patients the median duration of viral shedding was 14 days. ${ }^{9}$

In addition, limitation of availability and performance of molecular tests, cultural and economic challenges can compromise the ability of the containment strategy to control the dissemination of the virus, leading to the community transmission of SARS-CoV-2. In this scenario, the containment strategy must be substituted by a mitigation one, to prevent the increased number of hospitalizations that overwhelm the healthcare system with patients infected with SARS-CoV-2. Mitigation strategy is generally based on the recommendations of handwashing, closing of schools and businesses, travel limitations, social distancing, and home quarantine of mild symptomatic cases and groups of more susceptible individuals (e.g. elders and adults with chronic ailments such as diabetes and cardiovascular diseases. ${ }^{10}$ Mitigation measures are aimed to decrease the burden on the health care system, allowing the health care system to be better prepared for treatment of moderate and severe cases. Therefore, it is suggested that a combination of case isolation, social distancing of the entire population and either household quarantine or school and university closure are required.11 Nonetheless, although the mitigation strategy using non-pharmaceutical measures mentioned above were common sense among health agencies such as the World Health Organization (WHO), the Centers of Disease Control and Prevention of the United States (CDC), and the Brazilian Ministry of Health (MS), the recommendation for wearing masks by the general population was delayed.

The use of face masks is an attractive public health measure because of its low cost and speed of implementation: it is easier to execute than other more complicated strategies that have been successfully adopted in other countries to control the disease, such as mass testing, contact tracing, and hospitalization of positive patients even with mild forms of the disease. Currently, Brazil has adopted the universal use of face masks in public places. The use of face masks in Brazil by the general population has been increasing since April 1st, when the Minister of Health in Brazil published guidelines on how to make face masks and how to properly use them. ${ }^{12}$

\section{Rational for use of Face Masks as a Preventive Meaasure Against COVID-19}

Face masks, as other barrier prevention methods, can be used as a means to prevent individuals with confirmed or suspected infections from spreading respiratory contaminated droplets, i.e., as a source control measure. They can also be used to protect susceptible individuals from acquiring an infection, i.e., as an individual protective measure. ${ }^{13}$

There is considerable controversy in medical literature regarding nomenclature of respiratory particles of different sizes. WHO and CDC postulate that the particles of more than $5 \mu \mathrm{m}$ as droplets, and those less than $5 \mu \mathrm{m}$ as aerosols or droplet nuclei. Droplets tend to remain trapped in the upper respiratory tract (i.e., nose and throat), whereas aerosols or droplet nuclei have the potential to be inhaled into the lower respiratory tract (the bronchi and alveoli in the lungs). ${ }^{14}$

Respiratory droplets can be produced through breathing, talking, or coughing. ${ }^{15}$ Droplets smaller than 
$100 \mu \mathrm{m}$ in diameter will dry out before falling approximately 2 meters to the ground, forming the basis for the theory of droplet nuclei transmission depending on the size of the infected droplet. Droplet nuclei can be carried by the movement of air into the surrounding air spaces during daily activities as result of walking, or the opening of a door. ${ }^{16}$. It is said that most viral charge is transmitted in larger droplets, when we cough, sneeze, or talk. Minimizing the viral discharge into the atmosphere (i.e., use as control of source), particularly in larger droplets, is believed to be highly advantageous, and therefore, mechanical blockage in relatively simple masks is efficient in this case.

Filtration in masks uses three mechanisms. The first one is mechanical blockage of droplets that are of a size (e.g. $>5 \mu \mathrm{m}$ ) comparable to or larger than the mean space between the filaments that embody the mask as cellulose, cotton, etc. Moreover, large particles, and in this case, large virus-carrying droplets cannot penetrate the material. The second mechanism is filtration of very small particles or droplets (e.g., <200 nm) by direct collision with the mask filaments. Brownian motion causes very small droplets to move in a zig-zag motion and collide with the mask material. Filtration of very small particles is therefore relatively efficient. Respirators (e.g. N95) have the additional third filtration mechanism based on electrostatic attraction. Particles of intermediate size (e.g. 0.3-1 $\mu \mathrm{m}$ ) are attracted to the mask filament due to a residual electrical charge that they have. ${ }^{17}$

It is believed that the transmission of the small coronavirus takes place primarily transported in larger water droplets. However, since the SARS-CoV-1 (predecessor of the SARS-CoV-2) was found spreading in the air during the 2003 epidemic, it has been speculated that SARS-COV-2 be transmitted by the same mechanism. ${ }^{18}$ The possibility that SARS-CoV-2 is not only transmitted by virus-containing droplets ( 5 to 10 $\mu \mathrm{m}$ of diameter) but also by aerosols ( $\leq 5 \mu \mathrm{m})$ has created a popular question if face masks can be efficient against this virus. Although it is not clear that airborne transmission through aerosols is occurring with SARSCoV-2, as was proposed for SARS-CoV-1 outbreak in $2003,{ }^{19}$ more studies are necessary to ascertain the same for SARS-CoV-2. Nonetheless, the cautious approach assumes this possibility and reinforces the use of face masks as a critical barrier for reduction of transmission and infection. ${ }^{20}$

Transmission of SARS-CoV-2 by aerosol has long been recognized in the context of aerosol producing procedures in health care facilities by WHO, CDC, among other entities, but its role on community spread of disease was never admitted. ${ }^{18}$ SARS-CoV-2 in aerosol $(<5 \mu \mathrm{m})$ is viable for about 3 hours and can be found on any surface. However, the virus has been found to be more stable on plastic and stainless steel than on copper and cardboard. In this particular study, a viable virus was detected up to 72 hours on plastic and stainless steel, although with a greatly reduced viral titer. ${ }^{21}$

Covering the mouth and nose with a surgical or cloth face mask, instead of a respirator, can trap the large infectious droplets that are expelled when the wearer is speaking, coughing or sneezing, thereby protecting other people from the wearer (i.e. source control). However, it's value as an individual protective measure is questionable. Interesting, even though there is no direct evidence that a person wearing a face mask is protected from developing COVID-19, some studies have shown the effectiveness of surgical masks to protect against Influenza and other common seasonal coronaviruses. ${ }^{22}$ Moreover, there is some evidence that masks protect the wearer by reducing the inoculum of virus, which results in milder disease. ${ }^{23}$ The authors on this later study point out that the use of face masks might be in part responsible for asymptomatic and milder disease with lower mortality contrasting with the beginning of the pandemic, when face masks weren't being used by the general population.

\section{Medical Versus Non-Medical Face Masks}

A recent meta-analysis study found consistent evidence that in addition to other infection control measures, the use of medical masks (surgical masks and N95 respirators) by health professionals is effective at reducing the risk of contagion of respiratory diseases. ${ }^{24}$ However, the WHO emphatically states that fabric masks (for example, cotton or gauze) are not justified under any circumstances for use by health professionals. ${ }^{25}$ Evidence against the use of fabric masks by health professionals comes from a cluster randomized study in which health units were randomly assigned for one of three patterns of use of face masks: universal use of surgical masks, universal use of fabric masks (two layers of cotton) or use of masks according to the unit standard (control). The inclusion of a control arm without face masks was considered unethical and discarded. In this study, the number of respiratory infections and cases of flu-like syndrome was higher in the fabric mask group than in both the universal surgical mask group and the 
standard use group. However, the professionals who were in the group "universal use of surgical mask" received two masks per 8-hour shift, whereas those in the group that used the fabric masks were instructed to wear a single mask per shift, which should be washed daily after use with soap and water and worn again the following day. ${ }^{26}$ It is known that the prolonged use of face masks causes their saturation by the humidity of the breath, compromising their filtration capacity. ${ }^{27}$ Therefore, there was no valid comparison between the arms "universal use of surgical mask" and "universal use of cloth mask". Neither could the impact of using the cloth mask be evaluated versus the absence of a mask. Based on the results of the study, the authors concluded that the use of cloth masks by health professionals during care of sick patients is not to be recommended, which undoubtedly represented an advance on safety for healthcare professionals. The validity of the universal use of cloth masks for the general population, under the circumstances of a pandemic of a deadly respiratory infectious disease, was not addressed by this study.

The use of cloth face masks by the general population was already supported by a few scientific publications when the world assumed that the next pandemic would be an emerging influenza virus. ${ }^{28}$ These studies focused on the filtration capacity of cloth masks compared to surgical masks and respirators (N95, PFF-2 and similar). ${ }^{26,29}$ The results indicated that cloth masks have a lower filtration capacity (from around 50\% to 70\%, depending on the material) than surgical and respirator masks (more than 95\%), but also demonstrated that some filtration capacity exists depending on the type of fabric used in its manufacturing. These comparative studies considered that based on the risk to the overall population, although cloth masks are likely to reduce the exposure and infection spread at some level, they are not as efficient as surgical masks. For this reason, cloth masks are not recommended to health professionals, while it can be used by the general population.

Zangmeister et al tested the efficiency of 32 cloth materials used in face masks to filter nanometer-sized particles to micrometer-sized droplets calculating the filtration effectiveness of the fabric. ${ }^{30}$ They found that woven $100 \%$ cotton with high to moderate yarn counts had the best performance, while synthetic fabrics yield the poorest performance. Also, in this regard, Verma et al found that face masks with multiple layers of cotton quilting fabric and well fitted to the wearer face was the most effective to reduce droplets dispersal. Otherwise, loosely folded face masks and bandana-style covering were the least effective. ${ }^{31}$

In a recent study Aydin et al used mechanical methods to evaluate common cloth masks efficiency by challenging the fabrics with high and low-velocity droplets with use of a metered-dose inhaler loaded with a suspension of $100 \mathrm{~nm}$ fluorescent beads in distilled water to create the droplets range from $0.1 \mathrm{~mm}$ to $1 \mathrm{~mm}$. They found that effectiveness of fabric masks is dependable on four main factors. The breathability, the porosity, the hydro-affinity, and the fitness to the wearer face. ${ }^{32}$ The fabric of choice should be breathable as well as impermeable to the impact from high and low-velocity droplets. It is important to notice the anti-correlation of porosity and breathability of a fabric. With low fabric porosity, and bad fit to the wearer face, the flow of air is directed to the sides and other points of leakage on the mask, decreasing its effectiveness. Interestingly, the authors suggest that the high hydro-affinity of fabric on twolayered t-shirt face masks contribute to blocking high volume droplets. Moreover, it has been reported in another study that, independently of the fabric of choice for homemade face masks, the performance of efficient block droplets is dependent on the fit of the mask on the wearer face. ${ }^{33}$

\section{Universal Use of Face Masks for the General Population}

The arguments supporting the universal use of face masks by the general population have been debated since the start of the pandemic. As the disease progresses around the world, the decision to adopt such a feasible and potentially effective measure can result in a significant number of lives spared. Studies using mathematical models, with or without implementing lockdown, indicates that if the population wears a face mask $100 \%$ of the time combined with lockdown, the desired impact in mitigating the spread of COVID-19 such as flattening the curve and preventing secondary and tertiary waves of infections can be achieved. ${ }^{34,35}$ Most importantly, the results apply even considering face masks would have only $50 \%$ effectiveness at capturing viruses from respiratory droplets, i.e., similar to the effectiveness of cloth face masks. ${ }^{34}$ Also, these simulations indicate that use of face masks by the general public could potentially diminish community transmission and alleviate the burden of the pandemic.

The rationale for universal use of face masks comes from increasing evidence that viral transmission by 
infected individuals who have very mild symptoms, or who are asymptomatic, can have a more relevant role in the spread of the disease than previously assessed. ${ }^{36,37}$ Even more critical is the evidence that the immunity against SARS-CoV-2 from survivors of COVID-19 may only lasts 2 months. This means that previously infected individuals could potentially become re-infected and contagious. Therefore, carriers, when wearing the face mask, would avoid the contamination of susceptible people and the environment, as the face mask would create a barrier for the respiratory droplets eliminated during breathing. ${ }^{38}$

Respiratory etiquette has changed with time (Figure 1). In the past coughing/sneezing openly was accepted. Then with knowledge of airborne disease, covering a cough/sneeze with hands became the norm. Later, to prevent the spread of germs through contaminated hands or handkerchief, the use of the elbow to cover a cough/sneeze was recommended. Currently, the use of face masks is becoming socially acceptable to keep droplets to oneself, even in countries where it used to be a stigma (e.g. western countries).

Currently the recommendation for the general population is to wear a face mask all the time, except with people in the same quarantine pod or outside with good ventilation. Pods are a small self-containing network of people who limit their non-distance social interaction with one another. The implication is that even in someone's house if they receive a visitor from outside the pod, all people should wear a face mask while in the presence of a person from outside the pod. It is not recommended, however, for individuals with limited compliance and/or risk of suffocation with masks, such as those with mental health disorders, developmental disabilities, and children. For these groups, face shields may be considered as an alternative, even though they are inferior to face masks in preventing droplet transmission. ${ }^{25}$

However, the WHO has identified potential pitfalls from the use of face masks by the general population and indicated the following potential risks that should be carefully taken into consideration in any decision-making process: self-contamination by touching and reusing contaminated face masks; potential breathing difficulties depending on the type of face mask used; a false sense of security, potentially leading to lower adherence to other preventive measures such as physical distancing and hand hygiene; diversion of resources from effective public health measures, such as hand hygiene; and diversion of medical mask supplies and consequent shortage of proper masks for health-care workers. ${ }^{39}$

In a review study of the social behavior related to the use of face mask, the authors discussed that the adherence to proper use and disposal of masks would be difficult to implement in a short time, and the risk of improper use of it could end up facilitating the transmission of the virus, instead of decreasing

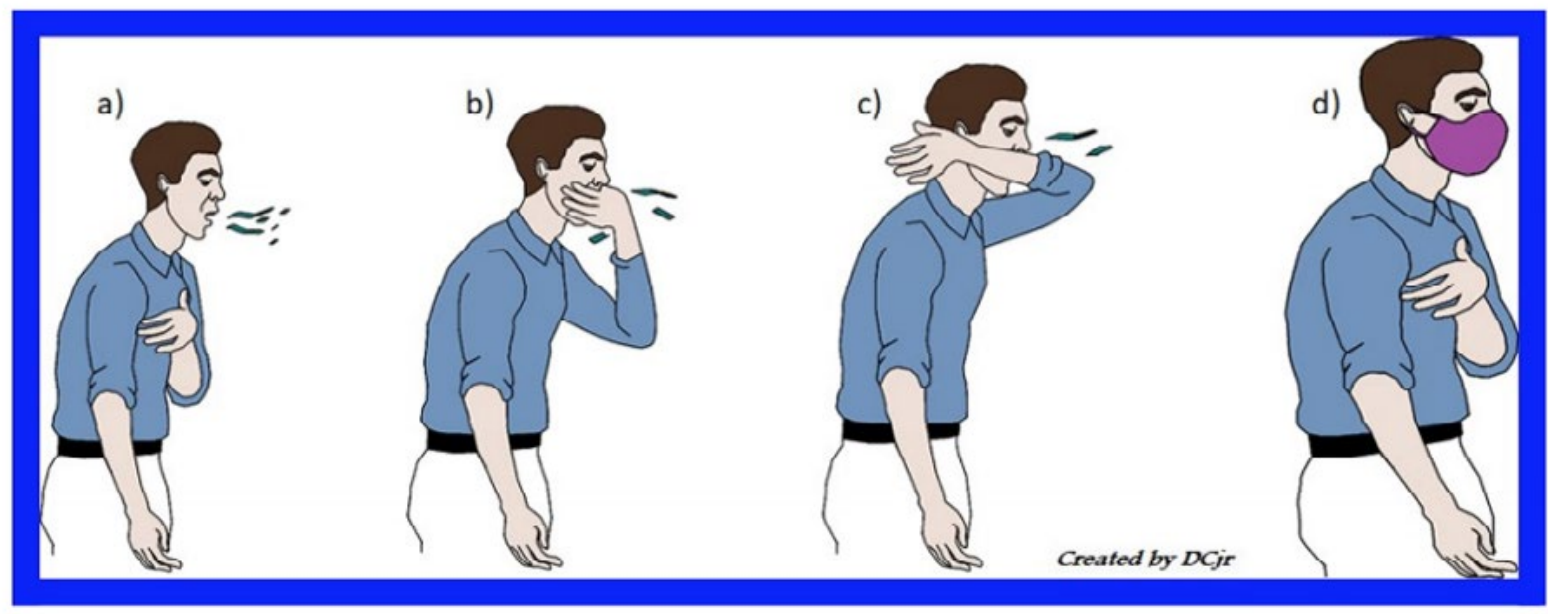

Figure 1. Respiratory etiquette evolution according to perceived social behavior. a) Openly coughing/sneezing without protection; b) cover cough/sneeze with hands; c) cough/sneeze into the elbow to prevent hands contamination; d) currently recommended use of face mask to keep drops to oneself 


\section{Review article}

it, which may offset its potential benefit. ${ }^{40}$ It points to the urgency to educate the general population on how to correctly use face masks, and why and when to quarantine asymptomatic and symptomatic patients. Therefore, with education, the use of face masks is an important tool for everyone, given their contribution to the well-being of the population.

Regarding the question of diversion of medical mask supplies, the use of cloth masks represents a cheap and feasible alternative for sparing those supplies while conferring protection for the population. Another advantage, especially relevant in low income countries, is the role of production and commercialization of cloth face masks as a source of income for families already abated by the economic crises. It is of paramount importance, however, to provide clear instructions not only regarding the adequate use of face masks by the population, but also the adequate confection and maintenance.

\section{Cloth Face Masks and Proper Care Procedures}

The necessity for clear guidelines on the use of cloth face masks has grown over time, and the benefits for wearing face masks by asymptomatic individuals became justifed by evidence that they possess some filtering capacity and are an alternative when surgical masks are in limited supply. It is clear that homemade masks are cheap, washable, easy to make, and can be used by the general population without imposing extra cost to local governments.
The recommendation for homemade face masks is to use $100 \%$ cotton fabric, such as cotton from T-shirts, antibacterial or normal pillow covers, or dish towels. ${ }^{41}$ Despite the lack of conclusive evidence regarding the benefit of adopting the universal use of face masks, the spontaneous use of them by the population is already noted. Initiatives for "do it yourself" projects to alleviate the burden of mass production of personal protective equipment (PPE) have stirred the imagination and creativity of the people wanting to engage in helping at this stressful moment. ${ }^{42}$ For example, concern regarding the effectiveness of homemade face masks in protecting the asymptomatic public has led to added treatments of starch to increase the pathogenic droplet absorption of the fabric, and salt to improve virus deactivation. ${ }^{43}$ These initiatives highlight that it is necessary to provide guidance on the best way to make homemade face masks in order to avoid risks related to inappropriate use.

Based on the best practices for use and manipulation of face masks by health authorities and on scientific publications presented in our review, we suggest a simple and safe procedure for use of the face mask in public. Figure 2 displays the correct use and handling of the face mask. The procedure includes covering the nose, mouth and chin with the face mask. Avoid uncovering the nose or the mouth to speak when in presence of others. To remove the mask, use the mask handle and never touch the front of the used mask.

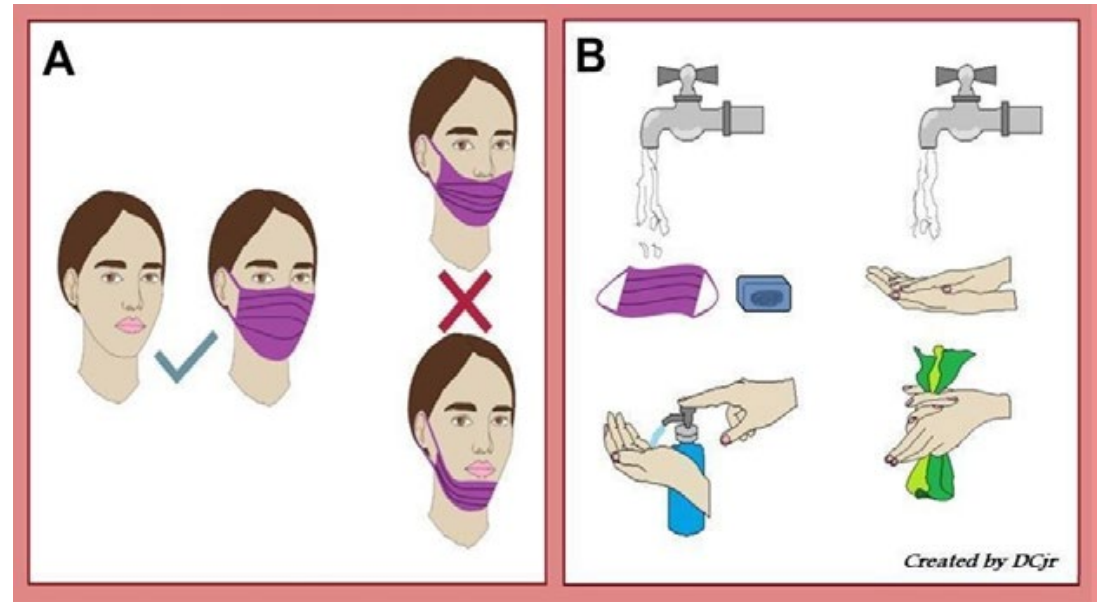

Figure 2. Recommendation of best practices on how to manipulate a mask as a non-pharmaceutical measure to combat COVID-19. A) Face masks must cover the nose, mouth and chin. Do not uncover your nose and mouth to speak nearby other people. To remove the mask, use the masks handle and never touch the front of used mask. B) After removing the mask, hands must be cleaned with hand-sanitizer with at least $60 \%$ ethanol and reusable masks must be washed with soap or laundry detergent 
After their use, the mask must be washed with soap or laundry detergent. The hands also need to be cleaned with soap and water, or hand-sanitizer containing at least $60 \%$ ethanol. More detailed information on how to prepare/manipulate the face mask can be found on Table 1.

\section{Conclusion}

From this literature review, we recommend the universal use of face masks by the general population as an additional resource to already established non-pharmacological measures as maintaining social distance (Figure 3) and hand hygiene, providing an

Table 1. Guidance and practical considerations - Adapted from WHO and Brazilian Health Surveillance National Agency (ANVISA) guidelines ${ }^{6,25}$

\section{Fabric selection:}

Choose materials that capture particles and droplets but remain easy to breathe through.

Avoid stretchy material for making masks as they provide lower filtration efficiency during use and are sensitive to washing at high temperatures.

Fabrics that can support high temperatures $\left(60^{\circ} \mathrm{C}\right.$ or more) are preferable.

\section{Construction:}

A minimum of three layers is required, depending on the fabric used: an inner layer touching the mouth and an outer layer that is exposed to the environment.

Choose water-absorbing (hydrophilic) materials or fabrics for the internal layers, to readily absorb droplets, combined with an external synthetic material that does not easily absorb liquid (hydrophobic).

\section{Mask management:}

Masks should only be used by one person - do not share your mask, even if it is clean.

Avoid use of make up on face while using face masks.

All masks should be changed after $3 \mathrm{~h}$ of continuous use or before, if soiled or wet; a soiled or wet mask should not be worn for an extended period of time.

Non-medical masks should be washed frequently and handled carefully, so as not to contaminate other items. Clothing fabrics used to make masks should be checked for the highest permitted washing temperature, which is indicated on the clothing label.

Non-woven polypropylene (PP) spunbonded may be washed at high temperature, up to $140{ }^{\circ} \mathrm{C}$. The combination of non-woven PP spunbonded and cotton can tolerate high temperatures; masks made of these combinations may be steamed or boiled.

Where hot water is not available, wash mask with soap/detergent at room temperature water, followed by either i) boiling mask for one minute OR ii) soak mask in $0.1 \%$ chlorine for one minute then thoroughly rinse mask with room temperature water, to avoid any toxic residual of chlorine.

Discard your mask if visibly damaged (i.e., torn, with less adjustment, deformation, etc.) or after 30 washes.

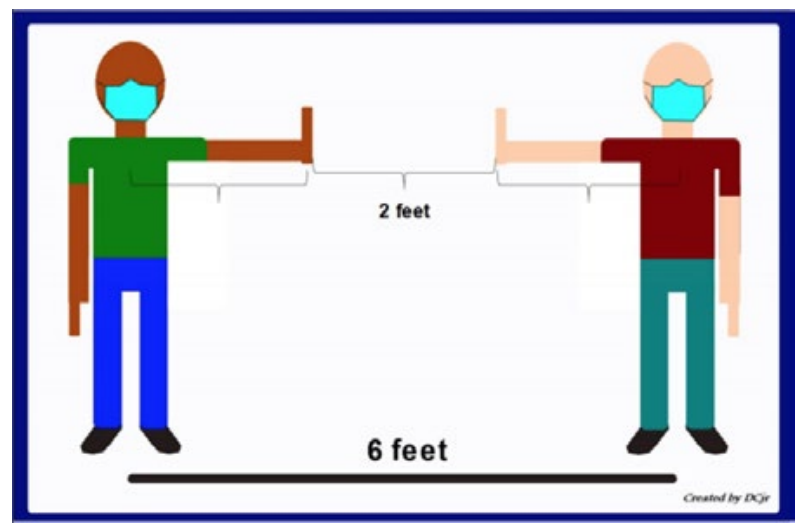

Figure 3. Use of face masks concomitant with social distance of at least 6 feet, or approximately 1.8 meters, between each person provide protection from respiratory droplets that are potentially contaminated with the virus. An approximation of the 6 feet distance can be achieved by the person estimating that from the center of their chest to the palm of your hand, with their arm stretched at a 90 degree' angle, is approximately 2 feet. By staying 3 times this length from another person, social distance is achieved 


\section{Review article}

efficient way to minimize the spread of COVID-19. A word of caution: for the homemade face mask to be beneficial it is necessary to follow the proper recommendations related to the composition of the face masks and proper handling, including proper hand hygiene. The authors endorse the selfless principle "I protect you, and you protect me". In this context, keeping your droplets to yourself regardless of current or previous health status. Every responsible citizen should wear face masks not only for self-protection and others but also to contribute to the end of the pandemic and start reversing the economic impact of the pandemic.

\section{Acknowledgment}

To Walter Margulis for his fundamental participation in the initial phases to this manuscript and his intellectual contribution during the entire process. Also to Gilberto Azevedo for reviewing the English in the manuscript.

\section{References}

1. Hartley DM, Perencevich EN. Public Health Interventions for COVID-19: Emerging Evidence and Implications for an Evolving Public Health Crisis. JAMA. 2020 May 19;323(19):1908-9.

2. Liu Y, Centre for Mathematical Modelling of Infectious Diseases $\mathrm{nCoV}$ Working Group, Funk S, et al. The contribution of pre-symptomatic infection to the transmission dynamics of COVID-2019. Wellcome Open Res. 2020 Apr 1;5:58.

3. Chaw L, Koh WC, Jamaludin SA, et al. SARS-CoV-2 transmission in different settings: Analysis of cases and close contacts from the Tablighi cluster in Brunei Darussalam. medRxiv. 2020 Jul 10;2020.05.04.20090043.

4. Keshtkar-Jahromi M, Sulkowski M, Holakouie-Naieni K. Public Masking: An Urgent Need to Revise Global Policies to Protect against COVID-19. Am J Trop Med Hyg. 2020 Jun;102(6):1160-1.

5. Cheng KK, Lam TH, Leung CC. Wearing face masks in the community during the COVID-19 pandemic: altruism and solidarity. The Lancet [Internet]. 2020 Apr 16 [cited 2020 May 27];0(0). Available from: https://www.thelancet.com/journals/ lancet/article/PIIS0140-6736(20)30918-1/abstract

6. ORIENTAÇÕES GERAIS - Máscaras faciais de uso não profissional [Internet]. [cited 2020 Sep 9]. Available from: http://portal. anvisa.gov.br/documents/219201/4340788/NT+M\%C3\%A1scaras.pdf/bf430184-8550-42cb-a975-1d5e1c5a10f7

7. Atkeson A. What Will Be the Economic Impact of COVID-19 in the US? Rough Estimates of Disease Scenarios [Internet]. Cambridge, MA: National Bureau of Economic Research; 2020 Mar [cited 2020 Jun 7] p. w26867. Report No.: w26867. Available from: http://www.nber.org/papers/w26867.pdf

8. Parodi SM, Liu VX. From Containment to Mitigation of COVID-19 in the US. JAMA. 2020 Apr 21;323(15):1441-2.

9. Long Q-X, Tang X-J, Shi Q-L, et al. Clinical and immunological assessment of asymptomatic SARS-CoV-2 infections. Nat Med. 2020 Jun $18 ; 1-5$.

10. Anderson RM, Heesterbeek $H$, Klinkenberg D, et al. How will country-based mitigation measures influence the course of the COVID-19 epidemic? The Lancet. $2020 \mathrm{Mar}$ 21;395(10228):931-4.

11. Ferguson N, Laydon D, Nedjati Gilani G, et al. Report 9: Impact of non-pharmaceutical interventions (NPIs) to reduce COVID19 mortality and healthcare demand [Internet]. Imperial College London; 2020 Mar [cited 2020 Jun 5]. Available from: http://spiral.imperial.ac.uk/handle/10044/1/77482

12. Máscaras caseiras podem ajudar na prevenção contra o Coronavírus [Internet]. [cited 2020 Jun 7]. Available from: https:// www.saude.gov.br/noticias/agencia-saude/46645-mascaras-caseiras-podvidasem-ajudar-na-prevencao-contra-o-coronavirus

13. Maclntyre $C R$, Chughtai AA. A rapid systematic review of the efficacy of face masks and respirators against coronaviruses and other respiratory transmissible viruses for the community, healthcare workers and sick patients. Int J Nurs Stud. 2020 Aug;108:103629.

14. Jayaweera M, Perera H, Gunawardana B, et al. Transmission of COVID-19 virus by droplets and aerosols: A critical review on the unresolved dichotomy. Environ Res. 2020 Sep;188:109819.

15. Anderson EL, Turnham P, Griffin JR, et al. Consideration of the Aerosol Transmission for COVID-19 and Public Health. Risk Anal. 2020;40(5):902-7.

16. Atkinson J, Chartier Y, Pessoa-Silva CL, et al. Respiratory droplets [Internet]. Natural Ventilation for Infection Control in Health-Care Settings. World Health Organization; 2009 [cited 2020 Jun 7]. Available from: https://www.ncbi.nlm.nih.gov/ books/NBK143281/

17. Tcharkhtchi A, Abbasnezhad N, Zarbini Seydani M, et al. An overview of filtration efficiency through the masks: Mechanisms of the aerosols penetration. Bioact Mater. 2020 Aug $11 ; 6(1): 106-22$.

18. Morawska L, Cao J. Airborne transmission of SARS-CoV-2: The world should face the reality. Environ Int. 2020 Jun 1;139:105730.

19. Tellier R, Li Y, Cowling BJ, et al. Recognition of aerosol transmission of infectious agents: a commentary. BMC Infect Dis. 2019 Jan 31;19(1):101.

20. Prather KA, Wang CC, Schooley RT. Reducing transmission of SARS-CoV-2. Science. 2020 Jun 26;368(6498):1422-4.

21. van Doremalen N, Bushmaker T, Morris DH, et al. Aerosol and Surface Stability of SARS-CoV-2 as Compared with SARSCoV-1. N Engl J Med. 2020 Apr 16;382(16):1564-7.

22. Leung NHL, Chu DKW, Shiu EYC, et al. Respiratory virus shedding in exhaled breath and efficacy of face masks. Nat Med. 2020 May;26(5):676-80.

23. Gandhi M, Beyrer C, Goosby E. Masks Do More Than Protect Others During COVID-19: Reducing the Inoculum of SARSCoV-2 to Protect the Wearer. J Gen Intern Med. 2020 Jul $31 ; 1-4$.

24. Offeddu V, Yung CF, Low MSF, et al. Effectiveness of Masks and Respirators Against Respiratory Infections in Healthcare 
Workers: A Systematic Review and Meta-Analysis. Clin Infect Dis Off Publ Infect Dis Soc Am. 2017 Nov 13;65(11):1934-42.

25. WHO-2019-nCov-IPC_Masks-2020.4-eng.pdf [Internet]. [cited $2020 \mathrm{Jul}$ 1]. Available from: https://apps.who.int/iris/bitstream/ handle/10665/332293/WHO-2019-nCov-IPC_Masks-2020.4eng.pdf?sequence $=1$ \&isAllowed $=y$

26. Maclntyre CR, Seale H, Dung TC, et al. A cluster randomised trial of cloth masks compared with medical masks in healthcare workers. BMJ Open. 2015 Apr 1;5(4):e006577.

27. van der Sande M, Teunis P, Sabel R. Professional and HomeMade Face Masks Reduce Exposure to Respiratory Infections among the General Population. PLoS ONE [Internet]. $2008 \mathrm{Ju}$ 9 [cited 2020 May 27];3(7). Available from: https://www.ncbi. nlm.nih.gov/pmc/articles/PMC2440799/

28. Garrett L. The Next Pandemic? Foreign Aff. 2005;84(4):3-23.

29. Davies A, Thompson K-A, Giri K, et al. Testing the Efficacy of Homemade Masks: Would They Protect in an Influenza Pandemic? Disaster Med Public Health Prep. 2013 May 22;7(4):413-8.

30. Zangmeister CD, Radney JG, Vicenzi EP, et al. Filtration Efficiencies of Nanoscale Aerosol by Cloth Mask Materials Used to Slow the Spread of SARS-CoV-2. ACS Nano. 2020 Jul 28;14(7):9188-200.

31. Verma S, Dhanak M, Frankenfield J. Visualizing the effectiveness of face masks in obstructing respiratory jets. Phys Fluids. 2020 Jun 1;32(6):061708.

32. Aydin O, Emon MAB, Cheng S, et al. Performance of Fabrics for Home-Made Masks Against the Spread of Respiratory Infections Through Droplets: A Quantitative Mechanistic Study [Internet]. Epidemiology; 2020 Apr [cited 2020 Aug 19]. Available from: http://medrxiv.org/lookup/ doi/10.1101/2020.04.19.20071779

33. Mueller AV, Eden MJ, Oakes JM, et al. Quantitative Method for Comparative Assessment of Particle Removal Efficiency of Fabric Masks as Alternatives to Standard Surgical Masks for PPE. Matter [Internet]. 2020 Jul 9 [cited 2020 Aug 19]; Available from: http://www.sciencedirect.com/science/article/pii/ S2590238520303647
34. Stutt ROJH, Retkute R, Bradley M, et al. A modelling framework to assess the likely effectiveness of facemasks in combination with 'lock-down' in managing the COVID-19 pandemic. Proc $\mathrm{R}$ Soc Math Phys Eng Sci. 2020 Jun 24;476(2238):20200376.

35. Eikenberry SE, Mancuso M, Iboi E, et al. To mask or not to mask: Modeling the potential for face mask use by the general public to curtail the COVID-19 pandemic. Infect Dis Model. 2020 Jan 1;5:293-308

36. Wei WE. Presymptomatic Transmission of SARS-CoV-2 - Singapore, January 23-March 16, 2020. MMWR Morb Mortal Wkly Rep [Internet]. 2020 [cited 2020 May 27];69. Available from: https://www.cdc.gov/mmwr/volumes/69/wr/mm6914e1.htm

37. Li R, Pei S, Chen B, et al. Substantial undocumented infection facilitates the rapid dissemination of novel coronavirus (SARSCoV-2). Science. 2020 May 1;368(6490):489-93.

38. Howard J, Huang A, Li Z, et al. Face Masks Against COVID-19: An Evidence Review. 2020 Apr 12 [cited 2020 May 24]; Available from: https://www.preprints.org/manuscript/202004.0203/v1

39. WHO-2019-nCoV-IPCPPE_use-2020.2-eng.pdf [Internet]. [cited 2020 Jun 7]. Available from: https://apps.who.int/iris/bitstream/ handle/10665/331498/WHO-2019-nCoV-IPCPPE_use-2020.2eng.pdf

40. Sim SW, Moey KSP, Tan NC. The use of facemasks to prevent respiratory infection: a literature review in the context of the Health Belief Model. Singapore Med J. 2014 Mar;55(3):160-7.

41. Mahase E. Covid-19: What is the evidence for cloth masks? BMJ [Internet]. 2020 Apr 7 [cited 2020 May 29];369. Available from: https://www.bmj.com/content/369/bmj.m1422

42. Chagas AM, Molloy JC, Prieto-Godino LL, et al. Leveraging open hardware to alleviate the burden of COVID-19 on global health systems. PLOS Biol. 2020 Apr 24;18(4):e3000730.

43. M. Mehedi R, Bhuyan MAH, Khan R, et al. A Simple Homemade Cloth Mask for Mass People in Covid-19: Salt-Starching Treatment on Fabric for Better Bioaerosol Filtration Efficiency. 2020 [cited 2020 May 24]; Available from: http://rgdoi.net/10.13140/ RG.2.2.26003.91681 